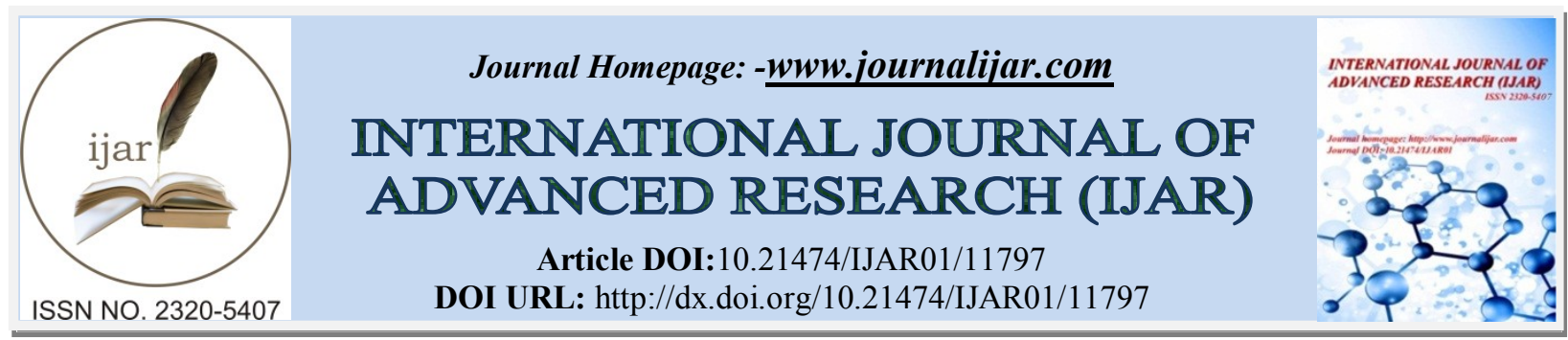

RESEARCH ARTICLE

\title{
THE PRIMARY METABOLITES OF SARDINE (SARDINA PILCHARDUS) IN THE MOROCCAN
} NORTH ATLANTIC

\section{Wahbi Abderrazik ${ }^{1}$, Seddik Nadia ${ }^{1}$, Hmimid Fouzia $^{2}$, Schahrakane Yassine ${ }^{1}$, Idali Hanane ${ }^{3}$, Errami Ahmed and Tazi Ouadia ${ }^{1}$}

1. Laboratory of Immunology and Biodiversity, Faculty of Sciences Ain Chock, Hassan 2 University, Casablanca, Morocco.

2. Laboratory of Biotechnology, Environment and Health - Faculty of Sciences El Jadida - University Chouaib Doukkali.

3. Laboratory of Health and Environment, Faculty of Sciences Ain Chock, Hassan 2 University, Casablanca, Morocco.

4. National Institute of Forensic Science of the Police, Casablanca, Morocco.

\section{Manuscript Info}

(...........................

Manuscript History

Received: 26 July 2020

Final Accepted: 31 August 2020

Published: September 2020

Key words:-

Sardina Pilchardus, Lipids, Protein,

Carbohydrate, North Atlantic

\section{Abstract}

Primary metabolites were determined in muscle, liver and gonads in sardines (Sardina pilchardus) captured in the Moroccan North Atlantic.It emerges from this study that in sardines, in the different seasons of the year, the lipid, protein and carbohydrate reserves are stored in the different organs. This important storage of metabolites in the gonads will undoubtedly be used for maturation; while the reserves stored in muscle and liver will be used for the production of energy necessary for catadromous migration.In addition, there are other biotic and abiotic factors that influence the use and storage of these metabolites such as the quality and quantity of foods and hydrological parameters.

Copy Right, IJAR, 2020,. All rights reserved.

\section{Introduction:-}

In Morocco, the fishing sector plays an important role on the economic and social plan, its national production was $1,353,780$ tons in 2014, which placed Morocco in the first rank of African production and in 17th place in the Globally (FAO, 2016). From an economic point of view, this sector plays a very important role; during the last decade, its contribution to the GDP (Gross Domestic Product) is of the order of $2.3 \%$ on average. On the social level, the fishing industry generates more than 170,000 direct jobs and 500,000 indirect jobs. $80 \%$ of national production is destined for seafood processing industries and $20 \%$ for the local market for the consumption of fresh products (MPM, 2014)

This small pelagic species exhibits great seasonal variation in primary metabolites. This seasonal change induced by the seasonal fluctuation of gonad maturation and reproductive activity and somatic growth (Silva, 2006) and of the body condition of the sardine in the Moroccan North Atlantic. (Zwolinski, Stratoudakis, \& Soares, 2001)

As in other pelagic species, primary metabolites play an important role in sardine nutrition for energy supply, as structural components of the body, and as essential membrane lipids (Hansen, 2008). Proteins for muscles and using sugars as a fuel for movement, however, the primary metabolites and its composition are associated with the life 
cycle and depend on external factors, such as environmental conditions and diet (Bandarra et al., 2011; Watters, Iwamura, Ako, Et Deng, 2012). The primary metabolite composition is the net result of complex dynamic relationships between several factors, the details of which are not fully understood. The main factors are: food intake; oxidative catabolism rates; kinetics of metabolic reactions, where diet seems to play the most important role (Cejas et al., 2004; Hixson, 2014).

Catch and survey samples have been the most common source to provide biological data on Atlantic sardines for several studies.

The aim of this work is to evaluate the changes of the primary metabolites of sardine in the Moroccan North Atlantic in the different seasons.

\section{Material and Methods:-}

Preparation of crude extracts:

All the operations are carried out at $4{ }^{\circ} \mathrm{C}$. Each tissue is cut into small pieces, then added with a buffer solution at pH 7.4 containing: 2 mM EDTA, $1 \mathrm{mM} 2 \beta$-mercaptoethanol, $1 \mathrm{mM}$ PMSF, $0.25 \mathrm{M}$ sucrose, $10 \mathrm{mM}$ HEPES.

In order to burst the cells of the tissues, we performed a grinding by ultra-turrax type (Apolymix ${ }^{\circledR}$ ) then a pottering (maximum speed, 10 turns) using a potter (Elvehjem ${ }^{\circledR}$ ), and end sonication by a sonicator of the type (Bandelin electronic $(\mathbb{B})$ followed by filtration on the biogas layers in order to eliminate cellular debris which has not been well ground. The collected filtrate is centrifuged at $11,200 \mathrm{~g}$ for $30 \mathrm{~min}$ at $4^{\circ} \mathrm{C}$. by type centrifugation (Hettich ${ }^{\circledR}$ ). The supernatant obtained represents the cytoplasmic fraction which will be used for assays of the enzymatic activities. The pellet is resuspended in a small volume of the buffer, the latter is centrifuged at $100,000 \mathrm{~g}$ for $30 \mathrm{~min}$ at $4{ }^{\circ} \mathrm{C}$ and purified to obtain the mitochondrial fraction which will be used for the mitochondrial enzymatic assays

\section{Protein determination:}

The proteins were quantified according to the technique of Bradford (1976) which is a sensitive, simple and rapid method. It is based on the use of the Bradford reagent (*) which contains coomassie blue G 250 which binds to the proteins giving a coloration ranging from brown for low concentrations to blue for high protein concentrations.

The volume of the samples $200 \mu \mathrm{l}$ is added with $800 \mu \mathrm{l}$ of Bradford's reagent. After 15 min of incubation at room temperature and in the dark, the absorbance of the color developed is measured at $595 \mathrm{~nm}$ using the spectrophotometer ( 3 Thermo electron corporation $\mathbb{B}$ ) and the unknown protein concentration is deduced by referring to the calibration curve produced using BSA (Bovine Serum Albumin).

\section{Electrophoresis under denaturing conditions (PAGE-SDS):}

The proteins are separated by vertical plate electrophoresis according to the technique of Laemmli (1970). It is carried out in a device for mini-gel $(8 \times 10 \mathrm{~cm})$, the wedges used have a thickness of $1 \mathrm{~mm}$.

The use of a denaturing agent such as sodium dodecyl sulfate (SDS) causes the quaternary structure to dissociate into monomeric forms, to which it binds. Under these conditions, the separation of proteins on the gel takes place only according to their size, since their charge density is made negative overall due to the presence of SDS.

\subsection{Preparation of gels}

$12 \%$ separation gel

1. Acrylamide $29.2 \%$ - Bisacrylamide $0.8 \% 4 \mathrm{ml}$

2. $1.5 \mathrm{M}$ Tris- $\mathrm{HCl} \mathrm{pH} 8.82 .5 \mathrm{ml}$

3. SDS $10 \% 100 \mu 1$

4. Double-distilled water $3.33 \mathrm{ml}$

5. Ammonium persulfate $10 \% 50 \mu 1$

6. TEMED $20 \mu 1$

7. $4 \%$ concentration gel

8. Acrylamide $29.2 \%$ - Bisacrylamide $0.8 \% 0.675 \mathrm{ml}$

9. $0.5 \mathrm{M}$ Tris- $\mathrm{HCl}, \mathrm{pH} 6.81 .25 \mathrm{ml}$

10. SDS $10 \% 50 \mu \mathrm{l}$

11. Double-distilled water $3.05 \mathrm{ml}$ 
12. Ammonium persulfate $10 \% 30 \mu \mathrm{l}$

13. TEMED $20 \mu 1$

14. Migration buffer

15. It is made up of the following solutions:

16. $25 \mathrm{mM}$ Tris- $\mathrm{HCl} \mathrm{pH} 8.3$

17. $320 \mathrm{mM}$ glycine

18. SDS $0.1 \%$

\section{Sample solubilization and migration:}

A volume containing $40 \mu \mathrm{g}$ of proteins is dissolved in $10 \mu \mathrm{l}$ of the loading buffer, the composition of which is as follows: $60 \mathrm{mM}$ Tris-HCL (pH 6.8), SDS 1\% (w/v), Glycerol 10\% (v/v), Bromophenol blue $0.01 \%(\mathrm{w} / \mathrm{v})$ and $\beta$ Mercaptoethanol $1 \%(\mathrm{v} / \mathrm{v})$, then heat for 3 minutes at $100^{\circ} \mathrm{C}$, and loaded into the wells of the gel. Migration is carried out at room temperature with a constant voltage of $100 \mathrm{~V}$.

\section{Coloring and discoloration of gels:}

The gels are colored overnight with stirring at room temperature with a $0.25 \%$ solution of Coomassie blue, in a "methanol - distilled water - acetic acid" mixture with a ratio (4/5/1). The gels are then decolorized in the same mixture without the coomassie blue.

\section{Determination of total lipids:}

From each of the samples of sardine fillets, the total lipids were extracted by the method of Folch et al (1957), Five grams of sample are ground with the potter, $20 \mathrm{ml}$ of methanol $(\mathrm{MeOH})$ and $10 \mathrm{ml}$ of chloroform $(\mathrm{CHCl})$ was added and vortexed for 2 minutes in a tube, $10 \mathrm{ml}$ of $(\mathrm{CHCl} 3)$ was added and stirred vigorously for 2 minutes. $10 \mathrm{ml}$ of distilled water was added and the mixture was again vortexed for 2 minutes. The layers were separated by centrifugation at $448 \mathrm{~g} / 10 \mathrm{~min}$. The lower layer was transferred to a vial with a Pasteur pipette. The method is repeated three times to exhaust the sample. After centrifugation, the $\mathrm{CHCl} 3$ phase was added to the first extract. Evaporation was carried out in a rotavapor at $45^{\circ} \mathrm{C}$. The weighing of the flask containing the lipid extract after evaporation of the solvent makes it possible to calculate the lipid content expressed in g per $100 \mathrm{~g}$ of sample, using the formula next:

$\mathrm{MG}=((\mathrm{P} 2-\mathrm{P} 1) / \mathrm{Pe}) * 100$

P2: weight of the balloon containing the lipids.

P1: weight of the empty balloon.

Pe: test take.

Gas chromatography coupled with mass spectrometer (GC / MS):

The lipid extracts are saponified beforehand using $\mathrm{KOH}(0.5 \mathrm{~N})$ and then methylated with a mixture of methanol-nhexane according to the method of Nasopoulou et al. (2012). The methyl esters of the fatty acids are then separated, quantified and analyzed by gas chromatography coupled with a mass spectrometer (Chromatograph: Shimadzu CLASS VP (GC17A. Kyoto, Japan) on a capillary column $60 \mathrm{~cm}$ long and $250 \mu \mathrm{m}$ in diameter. (Agilent, Santa Clara California, USA) The operating conditions for gas chromatography are as follows:

1. Injector and temperature sensor $\left(220^{\circ} \mathrm{C}\right.$ and $\left.225^{\circ} \mathrm{C}\right)$ respectively.

2. The oven temperature has been programmed to increase from $45^{\circ} \mathrm{C}$ to $240^{\circ} \mathrm{C}$ (at the rate of $20^{\circ} \mathrm{C}$ to $35^{\circ} \mathrm{C} /$ minute).

$1 \mu 1$ aliquots were injected with bicyanopropil phenyl silicone as the stationary phase and hydrogen was used as the carrier gas. Peak fatty acids were identified by comparison with methyl retention time and quantification of alpha male acids was made by reference to an internal standard by palmitic acid (C16: 0).

\section{Determination of total sugars:}

The total sugars are determined according to the method of Dubois et al, (1956), the principle of which is based on the following reaction: the sample volume $100 \mu \mathrm{l}$ is added with $200 \mu \mathrm{l}$ of phenol and $1 \mathrm{ml}$ of concentrated sulfuric acid causes, when hot, the departure of several water molecules from the oses. This dehydration is accompanied by the formation of a hydroxy-methylfurfural (HMF) in the case of hexose and of a furfural in the case of a pentose and which will give colored complexes (yellow-orange). The intensity of the coloring is proportional to the concentration of the ose. Optical density is measured at $490 \mathrm{~nm}$ using a spectrophotometer. 


\section{Resultants:-}

In this study, we investigated the monthly variations of the overall chemical composition of sardine: Sardina pilchardus in the Moroccan North Atlantic region. The present work, which concerns the variations of proteins, sugars and lipids in the different organs of the sardine (muscle, gonad and liver), in order to determine these modifications according to the months.

\section{Determination of sugars:}

The sugar content in the muscle, gonad and liver organs shows variation throughout the year as well as the variation is not very similar for the two sexes with a maximum value in February and a minimum value in June, knowing that the succession periods of sexual maturation and organ development even lead to significant fluctuations in the state of sugars.
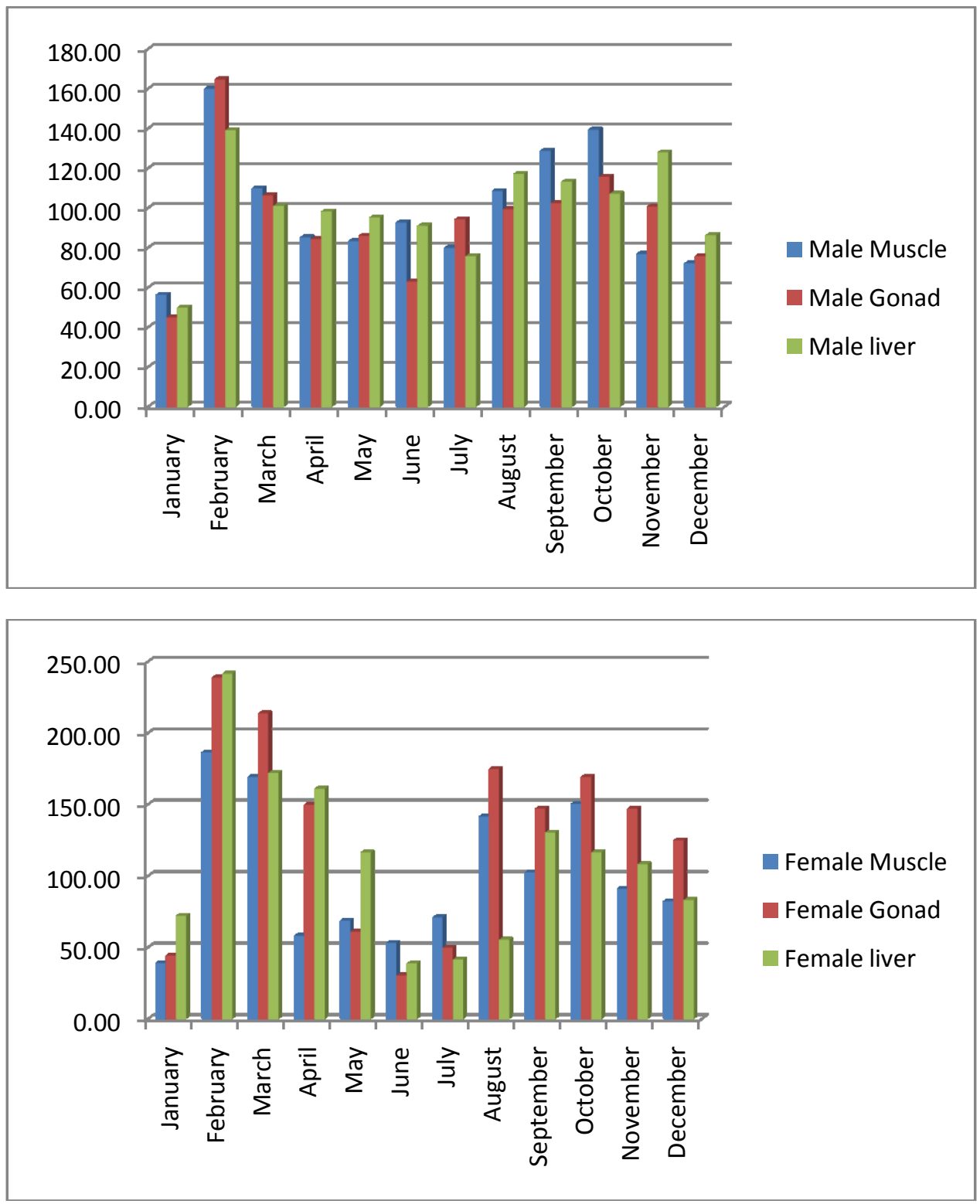

Evolution of the sugar level of sardines 


\section{Protein determination:}

The monthly evolution of the sardine protein content is shown in figure 30 . We observed an increase in this content from April to reach a maximum value in August for the male and female gonads, then we noted a slight increase in the protein content in the same period for the liver, at the end we observed a gradual increase for the muscle for both sexes.
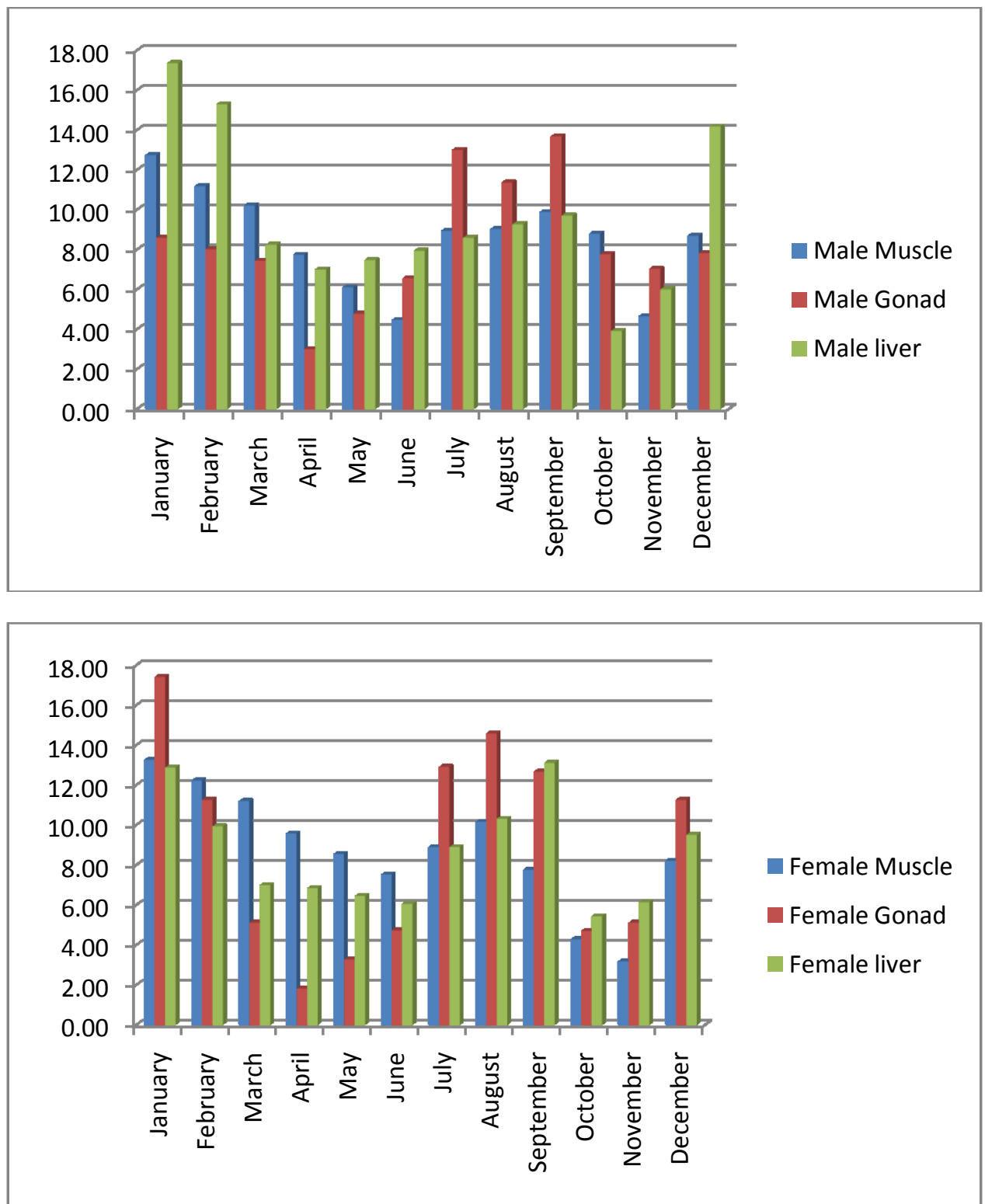

Evolution of the protein level of sardines

\section{SDS-PAGE electrophoresis:}

Electrophoresis is the displacement of an ionized particle in a given electric field. The principle of this method is therefore based on the amphoteric nature of proteins. Ionization involves the acidic or basic end groups, amino residues that determine the net charge of the protein. The speed of protein migration inside the support (starch or polyacrylamide gel) depends on the net charge at a given $\mathrm{pH}$, the molecular weight and the different interactions that the protein can have with its solvent. 


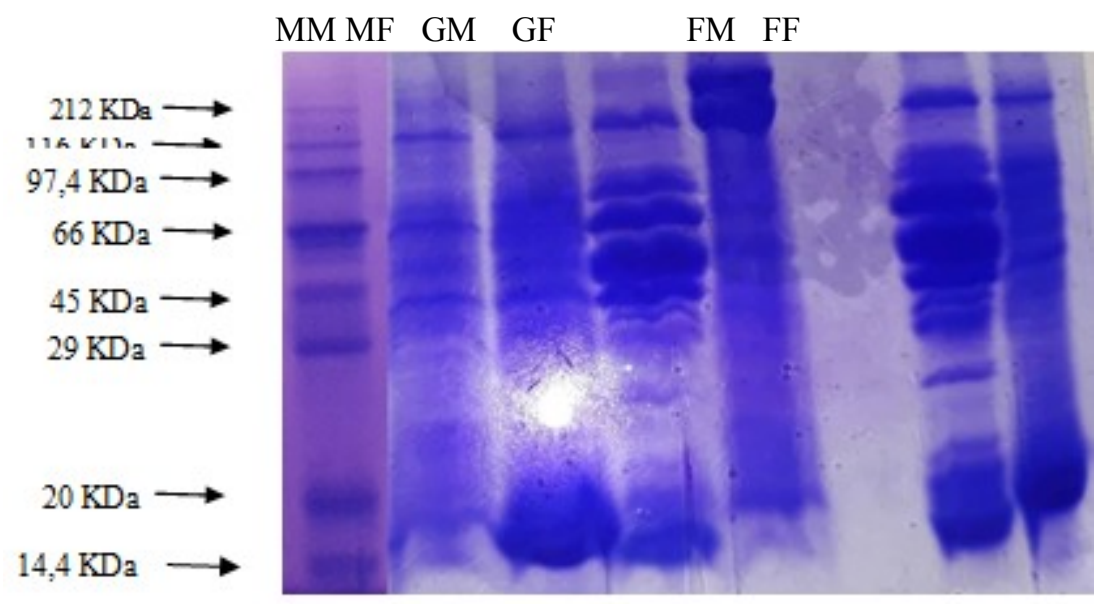

Photo: SDS-PAGE 1PM electrophoretic profile: molecular weight markers (myosin (212KDa), galactosidase $(116 \mathrm{KDa})$, phosphorylase b $(97.4 \mathrm{KDa})$, BSA $(66 \mathrm{KDa})$, ovalbumin $(45 \mathrm{KDa}), 1$ carbonic anhydrase $(29 \mathrm{KDa})$, inhibitor trypsin (20 KDa) and lysozyme (14.4 KDa)), MM: male muscle, MF: female muscle, GM: male gonad, GF: female gonad, FM: male liver, FF: female liver

\section{Determination of total lipids:}

The assays carried out on Sardina pilchardus during the aforementioned periods gave rise to the results shown in Table 13, these are the amounts of lipids in the various organs of the sardine reported in the fresh masses. During the period of our study, we note that the content of muscle lipids varies depending on the month with a maximum value of $0.05 \mathrm{~g} / \mathrm{g}$ for males and for females $0.07 \mathrm{~g} / \mathrm{g}$ of the mass of the fish. While the gonad lipid content is $0.03 \mathrm{~g} / \mathrm{g}$ for males and $0.05 \mathrm{~g} / \mathrm{g}$ for females. The lipid levels in the liver in males and females are the same $0.02 \mathrm{~g} / \mathrm{g}$.

\begin{tabular}{|l|l|l|l|l|l|l|}
\hline Month & Male Muscle & Male Gonad & Male Liver & Female Muscle & Female Gonad & Female Liver \\
\hline January & 0.01 & 0.03 & 0.01 & 0.02 & 0.03 & 0.01 \\
\hline February & 0.03 & 0.03 & 0.01 & 0.04 & 0.04 & 0.02 \\
\hline March & 0.03 & 0.01 & 0 & 0.03 & 0.02 & 0 \\
\hline April & 0.01 & 0 & 0 & 0.02 & 0 & 0 \\
\hline May & 0.01 & 0 & 0 & 0.02 & 0 & 0 \\
\hline June & 0.03 & 0 & 0 & 0.03 & 0 & 0 \\
\hline July & 0.04 & 0.01 & 0 & 0.04 & 0.02 & 0 \\
\hline August & 0.05 & 0.01 & 0 & 0.06 & 0.01 & 0 \\
\hline September & 0.05 & 0.02 & 0.01 & 0.07 & 0.05 & 0.01 \\
\hline October & 0.05 & 0.01 & 0.01 & 0.05 & 0,04 & 0.01 \\
\hline November & 0.04 & 0.01 & 0.02 & 0.03 & 0.01 & 0.02 \\
\hline December & 0.02 & 0.01 & 0.01 & 0.02 & 0.01 & 0.01 \\
\hline
\end{tabular}

Quantity of lipids of sardine

\section{Analysis of total fatty acids:}

The fatty acids contained in the three organs were analyzed before performing the lipid class analysis. These results are reported in Table X. For all the analyzes, the majority fatty acid is palmitic acid.

The distribution in AGS, MUFA and PUFA of fatty acids in the different organs of the sardine is represented respectively $40.1 \%, 27.7 \%$ and $32.2 \%$ for the liver, $42.4 \%, 21.31 \%$ and $36.29 \%$ for muscle, $38.55 \%, 32.2 \%$ and $38.25 \%$ for gonads. The most important fatty acid families are respectively w3 about $22.5 \%, 28.85 \%$ and $30.2 \%$, for w6 about $11.7 \%, 7.2 \%$ and $6.68 \%$.

Distribution of fatty acids (\%) within the three organs (liver, muscle and gonad) of the sardine 


\begin{tabular}{|l|l|l|l|}
\hline & Liver & Muscle & Gonad \\
\hline C14:0 & 11,5 & 12,4 & 10,87 \\
\hline C16:0 & 21,3 & 21,6 & 19,74 \\
\hline C18:0 & 5,5 & 6,1 & 6,74 \\
\hline Other & 0,5 & 0,8 & 0,4 \\
\hline Saturated & 1,3 & 1,5 & 0,8 \\
\hline C16:1 & $\mathbf{4 0 , 1}$ & $\mathbf{4 2 , 4}$ & $\mathbf{3 8 , 5 5}$ \\
\hline C18:1 & 9,2 & 10,43 & 10,73 \\
\hline C20:1 & 10,9 & 8,95 & 8,82 \\
\hline C22:1 & 3,4 & 0,16 & 1,45 \\
\hline Other & 3,4 & 1,4 & 2,2 \\
\hline monounsaturated & 0,8 & 0,37 & - \\
\hline C16:2n4 & $\mathbf{2 7 , 7}$ & $\mathbf{2 1 , 3 1}$ & $\mathbf{2 3 , 2}$ \\
\hline C18:2n6 & 1,4 & 0,4 & 0,82 \\
\hline C18:3n3 & 6,8 & 6,08 & 5,89 \\
\hline C18:4n3 & 0,6 & 0,24 & 1,23 \\
\hline C20:4n3 & 1,1 & 0,4 & 0,1 \\
\hline C20:5n3 & 1,5 & 0,96 & 1,34 \\
\hline C22:5n3 & 6,5 & 10,95 & 11,34 \\
\hline C22:6n3 & 1,1 & 1,1 & 0,7 \\
\hline polyunsaturated & 13,2 & 16,16 & 16,83 \\
\hline $\mathbf{\omega} 3$ & $\mathbf{3 2 , 2}$ & $\mathbf{3 6 , 2 9}$ & $\mathbf{3 8 , 2 5}$ \\
\hline $\mathbf{2} \mathbf{6}$ & 22,5 & 28,85 & 30,2 \\
\hline $\mathbf{\omega} 3 / \mathbf{\omega 6}$ & 11,7 & 7,2 & 8,68 \\
\hline & 1,92 & 4,01 & 3,48 \\
\hline
\end{tabular}

\section{Discussion:-}

The comparison of the three primary metabolites lipid, protein and carbohydrate of the different studied organs of the sardine that we have studied, allows noticing that at all levels there is variation over the whole year. This variation is well recorded during the breeding season than during the sexual rest period. This could be explained by the use of part of this primary metabolite for reproductive needs to which would be added the energy needs allowing the fish to overcome the winter season.

Lipid deposits increase steadily during ontogeny. For the liver is not involved in the transfer of lipid reserves necessary for vitellogenesis. This confirms the classification of S. pilchardus among fatty fish characterized by lipid accumulation in muscles and by subcutaneous fat deposition, unlike lean fish where lipids accumulate in the liver before passing to the gonads (Xu et al 2000). In sardines, lipid storage takes place in the muscles, within or between muscle fibers (Yashodhara et al 2009). Maximum adiposity values are recorded at the onset of maturation of the genitals, while they decrease in December and January when the gonad mass is maximum, thus confirming that S. pilchardus uses muscle and mesentery lipid reserves for develop gametes. The increase in fattening is due to the availability of food resulting from significant plankton production linked to the upwelling season (Makaoui et al 2008). In fact, the sardine feeds intensively in summer and stores these energy reserves which will be allocated gradually to the maturation of the gonads and to reproduction. The adaptation condition of females is generally superior to that of males regardless of the study area. This indicates that the mass of females is greater than that of males for the same size (Bacha et al., 2007). Environmental conditions, in particular the temperature factor (Makaoui et al., 2005) as well as the quality and quantity of feed directly influence fattening. At the same time, the protein storage capacity is extremely limited. Fish do not have a reserve form of protein, such as glycogen for sugar or adipose tissue for lipids. If the amino acids that come from protein digestion are not used immediately by the body, they are converted into glucose for energy (Reynolds et al, 2003).

When the glycogen stock is depleted, such as during a bad weather period or a prolonged migration, and if the adipose tissue is poorly developed, the musculature therefore acts as a kind of reserve of amino acids.

The chemical composition of fish varies considerably from species and individual to individual depending on age, sex, environment and season. Changes in the chemical composition of fish are closely related to their diet, migratory 
movements and sexual changes in relation to spawning. Fish will have periods of starvation for natural or physiological reasons (such as migration and spawning) or because of external factors such as lack of food. Usually spawning, whether it occurs after a long migration or not, is very energy intensive. Fish that have energy reserves in the form of lipids will rely on these. Species that migrate for a long time, before reaching specific spawning sites, can use protein in addition to lipids for energy and therefore deplete their stores of both lipids and proteins. This leads to a general reduction in the physical condition of the fish. In addition, most species feed very little during their spawning migration and are therefore unable to obtain energy from food (Kacem, 2000).

One method, useful classified fish in lean species and fatty species, consists in considering as lean the fish which store lipids only in the liver and as fatty fish the fishes retaining the lipids in fat cells distributed in other tissues of the body. Typically lean species are ground fish such as cod and hake. Fat species include pelagic like sardines, sardinella, herring, and mackerel. Some species store lipids only in limited parts of their body tissue, or in smaller amounts than typically fatty species and are therefore called semi-fatty species, (mullet and shark) (Aymen et al 2010) .

Our study shows the seasonal variation of fat deposition in sardines. We see that lipid levels in different tissues vary widely and this is consistent with the work of Shepherd et al, 2005. Lipid stores are typically used for large spawning migrations and gonad development.

\section{Conclusion:-}

The comparison of the primary lipid, protein and carbohydrate metabolites in different muscle, liver and gonad organs of sardines in the Moroccan North Atlantic that we have studied, allows us to notice that at all levels there are fluctuations of the three metabolites in the different seasons of the year which is well noticed in the breeding period (February) than in the period of sexual rest (August). This could be explained by the use of a part of the metabolites for the needs of reproduction to which would be added the energy needs allowing the fish to overcome the winter season.

Furthermore, the results of this study show that the primary metabolites are stored and used unevenly in the sardine organs as needed.

\section{Bibliography:-}

1. FAO, (2016). Report of the working Group on the assessment of small-pelagic fish off northwest Africa. FAO Fisheries and Aquaculture $\mathrm{N}^{\circ}$ Report, 882,117-118pp.

2. MPM (Ministère des Pêches Maritimes), 2014. Rapport d'activité Département de la Pêche Maritime. Rabat, Maroc. 61 pp. Accessible en ligne à http://www.mpm.gov.ma/wps/wcm/connect/640ef32b-92b1-428fbbbfa014ba1 ff607/Rapport_activite_2014.pdf?MOD=AJPERES\&CACHEID=640ef32b 92b1-428f-bbbfa014ba1ff607.

3. Zwolinski, J. Stratoudakis, Y. Soares, E. (2001). Intra-annual variation in the batch fecundity of sardine off Portugal. J. Fish Biol. 58(6):1633-1645.

4. Hansen, O. Berge, J. Hillestad, GM. Krogdahl, M, Galloway, Å. Holm, T. Holm, H. Ruyter, JB. (2008) apparent digestion and apparent retention of lipid and fatty acids in Atlantic cod (Gadus morhua) fed increasing dietary lipid levels. Aquaculture, 284: pp. 159-166.

5. Bandarra, N. M., Rema, P., Batista, I., Pousão-Ferreira, P., Valente, L. M. P., Batista, S., \& Ozório, R. (2011). Effects of dietary n-3/n-6 ratio on lipid metabolism of gilthead seabream (Sparus aurata). European Journal of Lipid Science and Technology, 113, 1332-1341.

6. Watters, C. Iwamura, S. Ako, H. Deng, DF. (2012). Nutrition Considerations in Aquaculture: The Importance of Omega-3 Fatty Acids in Fish Development and Human Health. Honolulu (HI): University of Hawaii. 7 p. (Foods and Nutrition Series; FN-11).

7. Cejas, P. Enrique, C. Cristobal, B. Javier, D. Enrique, E. Andrés, R. María, S. Miguel, A. Juan, A. Vara, A. Rosario, P. Manuel, G. (2004) Implications of oxidative stress and cell membrane lipid peroxidation in human cancer 15(7):707-19.

8. Hixson, SM. Parrish, CC. (2014). Substitution of fish oil with camelina oil and inclusion of camelina meal in diets fed to Atlantic cod (Gadus morhua) and their effects on growth, tissue lipid classes and fatty acids. J Anim Sci., 92 (3): 1055-1067 
9. Bradford M. (1976). A rapid and sensitive method for the quantization of microgram quantities of protein utilizing the principle of protein dye binding, Analytical Biochem., 72: 248-254.

10. Folch, J. lees, M. Stanley, G.H.S. (1957). A simple method for the isolation and purification of total lipids from animal tissues. J. biol. Chem., 226, 497-509.

11. DuBois, M. Gilles, K. Hamilton, J. Rebers, P. Smith, F. (1956). Colorimetric method for determination of sugars and related substances. Analytical Chemistry, 28(3), 350-356.

12. Xu, X. Balchen, S. Jonsson, G. Adler-Nissen, J. (2000). Production of structured lipids by-lipase-catalyzed interesterification in flat membrane reactor. JAOCS. 77:035-141

13. Yashodhara, BM. Umakanth, S. Pappachan, JM. Bhat, SK. Kamath, R. Choo, BH. (2009) Omega-3 fattu acids: a comprehensive revieuw of their role in health and disese. Postgrad Med J. 85(1000):84-90

14. Makaoui, A. Orbi, A. Hilmi, K. Zizah, S. Larissi, J. \& Talbi, M. (2008). «L’upwelling des

15. côtes Atlantique du Maroc entre 1994 et 1998». C. R. Geoscience 337, pp. 1518-1524.

16. Bacha, M. Amara, R. Benmansour, N. Brylinski, JM. Moali, A. Mahé, K. (2007) Âge, croissance et régime alimentaire de l'anchois (Engraulis encrasicolus L.) dans la Baie de Bénisaf (SO Méditerranée, Ouest Algérien)., ;34(1): 47-57.

17. Makaoui, A. Orbi, A. Hilmi, K. Zizah, S. Larissi, J. \& Talbi, M. (2005). L'upwelling de a côte atlantique du Maroc entre 1994 et 1998. C. R. Geoscience 337, pp. 1518-1524.

18. Reynolds, JA. Tanford, C. (2003). Nature's Robots: A History of Proteins (Oxford Paperbacks) . New York, New York: Oxford University Press. p. 15.

19. Kacem, A. (2000) Transformations morphologiques et histologiques du squelette du saumon Atlantique(Salmo salar L.) au cours de son cycle vital ; Thèse de Doctorat

20. Aymen, C. Seiji, O. Ichiro, A. Natheer, A. (2010). Classification of fish schools based on evaluation of acoustic descriptor characteristics ; Fisheries Science 01/2010; 76(1):1-11

21. Shepherd, CJ. Pike, IH. Barlow, SM. (2005). Sustainable feed ressouces of marine origin. Eur. Aquaculture Soc. Special Publication. 35:59-66. 